ФИЛИН Никита Александрович - доктор исторических наук, доиент; заведующий кафедрой современного Востока Российского государственного гуманитарного университета (125993, Россия, ГСП-3, г. Москва, Миусская пл., 6; n.filin@rggu.ru)

\title{
ОСОБЕННОСТИ УПОТРЕБЛЕНИЯ ТЕРМИНА «ИМАМ» ПО ОТНОШЕНИЮ К ОСНОВАТЕЛЮ ИСЛАМСКОЙ РЕСПУБЛИКИ ИРАН АЯТОЛЛЕ ХОМЕЙНИ
}

\begin{abstract}
Аннотация. В современном Иране по отношению к первому верховному лидеру страны аятолле Хомейни постоянно используется термин «имам». В иранской шиитской традиции понятие «имам» применяется не только к руководителям молитвы верующих, но и к двенадцати имамам - потомкам пророка Мухаммада, которые считаются непогрешимыми. Последний имам, Махди, по верованиям шиитов, ушел в сокрытие и должен будет вернуться. В народном сознании иранцев образ сильного лидера Хомейни в какой-то степени связывался с образом имама Махди. Однако иранское духовенство отрицало возможность сравнения Хомейни с непорочными имамами и использовало термин «имам» в его исконном значении - «предводитель общины мусульман», подчеркивая выдающуюся роль Хомейни в руководстве шиитами и Исламской революции. После прихода к власти Хомейни был провозглашен наместником имама Махди, что еще усилило его религиозный и политический статус и дало ему возможность осуществлять почти неограниченную власть.
\end{abstract}

Ключевые слова: Хомейни, Махди, имам, предводитель, легитимность, духовенство

И звестно, что по отношению к основателю и первому верховному лидеру Исламской республики Иран аятолле Рухолле Мусави Хомейни в персоязычной историографии и публицистике, наряду с исконным термином «рахбар» (перс. - руководитель), очень часто употребляется также термин «имам» арабского происхождения. В суннитском исламе понятие «имам» используется для обозначения предстоятелей на молитве, а иногда - духовных лидеров мусульманской общины. В иранской шиитской традиции оба эти значения тоже существуют, но у шиитов понятие «имам» в первую очередь используется для обозначения двенадцати шиитских имамов, считающихся безгрешными. Последний из них, имам Махди, ушел в сокрытие, и верующие шииты ожидают его возвращения для того, чтобы он устранил все формы угнетения и установил справедливость во всем мире. В данном исследовании будет рассмотрено, в каком значении термин «имам» употребляется по отношению к аятолле Хомейни и можно ли допустить определенную связь между этим титулом и двенадцатью шиитскими имамами.

Аятолла Хомейни в начале 1960 -х гг. активно включился в политику и стал выступать против шахского режима, в результате чего его в 1964 г. выслали в Турцию, откуда он перебрался вначале в Ирак, а в 1978 г. - в Париж. К тому времени он пользовался очень большим авторитетом среди верующих шиитов и имел миллионы сторонников по всему Ирану, которые надеялись с его помощью избавиться от репрессивного режима шаха и установить правление, приближенное к религиозному идеалу. То, что Хомейни пребывал в столице Франции, вдали от родины, и передавал свои поручения и сообщения с помощью представителей, позволяло его почитателям и последователям сравнивать его с Сокрытым имамом. В стране распространялись слухи о якобы сверхъестественных явлениях, связанных с аятоллой. Так, в Тегеране циркулировал слух, что 27 ноября 1978 г. на полной луне можно будет увидеть лик Хомейни, 
правда, смогут его лицезреть только праведные мусульмане. В результате несколько миллионов иранцев в этот день взобрались на холмы в ожидании этого явления, а многие из них впоследствии уверяли, что им действительно удалось увидеть образ аятоллы [Taheri 1985: 138]. По случаю данного явления были устроены празднества в мечетях, а духовенство истолковало это как знак скорого появления имама Махди, поскольку существует предание, что он придет, когда солнце взойдет на западе. Муллы интерпретировали лик Хомейни на луне как исполнение этого предания, поскольку он в то время был на Западе (в Париже), а при этом его лик воссиял на луне, как солнце [Юртаев 1993: 111].

Во время Исламской революции верующие иранцы ждали возвращения Хомейни так же, как ждали и Сокрытого имама. В день его возвращения в лозунгах встречавших его людей постоянно упоминалось слово «имам», а сами они были убеждены, что пришло время всеобщей справедливости и благоденствия. В некоторых лозунгах можно было видеть прямые параллели с имамом Махди: например, в них использовались слова «ожидание» и «господин», традиционно употребляющиеся по отношению к Сокрытому имаму [Пархизкар 2014: 161]. Таким образом, среди простых верующих было очевидно сопоставление образа Хомейни с образом имама Махди.

После революции была принята конституция, по которой Хомейни передавались очень большие полномочия. За ним был закреплен термин «имам», а сам он при этом фактически был признан посредником, интерпретирующим волю Сокрытого имама. По мнению Н.Д. Кулюшина, можно усмотреть определенную связь термина «имам» по отношению к Хомейни с непорочными шиитскими имамами. В частности, он считает, что аятолла во многом напоминал имамов, поскольку был духовным вождем иранского народа и шиитской общины, оказался во главе революции, установившей религиозное правление, а кроме того, был авторитетным богословом. Его также воспринимали как защитника религии от западных государств и их союзников. Но все же невозможно признать Хомейни равным двенадцати имамам, поскольку его правление легитимировалось в т.ч. через народ, а не только через Бога, он не был прямым потомком ни одного из имамов, и, кроме того, он, как обычный человек, мог совершать ошибки [Кулюшин 2009: 104-105].

Власть Хомейни в Иране была практически неограниченной, что напоминало абсолютную власть непорочных имамов над верующими, которая так же, как и в случае Хомейни, основывалась на уважении народа к их богословским познаниям и их борьбе за утверждение ислама. Необходимость обладания такой властью была подкреплена религиозными аргументами. Так, среди иранских богословов и ученых есть точка зрения, что понятие велайат-е факих (правление богослова), использовавшееся Хомейни, имеет свои корни в концепции велайат-е имаман (правление непорочных имамов). Согласно ей, простые люди должны во всем слушаться правящего богослова или же непогрешимого имама, которому дается титул вали-йе амр (управляющий наместник), потому что он, в свою очередь, передает населению волю Бога. Считается, что сами люди без этого наместника не в состоянии организовать успешное управление, потому что склонны заблуждаться. Вначале таким способом общиной верующих управляли пророк Мухаммад и пречистые имамы, а после сокрытия последнего имама право на управление перешло к представителям имамов богословам [Борзуни 1999: 75]. Здесь очевидны два источника легитимности велайат-е факих. Во-первых, правящий богослов является представителем имама Махди, а во-вторых - представителем Бога, поскольку реализует образ правления, наиболее угодный Богу.

Можно сказать, что простой народ Ирана, воспитанный на рассказах о 
сокрытии и возвращении имама Махди, хотел видеть во главе государства сильного и справедливого правителя, похожего на него. Поэтому народ перенес мессианские черты на харизматичную личность Хомейни и начал его усиленно поддерживать, что помогло аятолле укрепить свою власть и одержать победу над соперничавшими с ним представителями высшего духовенства, прежде всего над великими аятоллами Мухаммадом Шариатмадари и Мухаммадом Мараши Наджафи, которые выступали против концепции велайат-е факих и считали, что духовенство не должно вмешиваться в политику [Дорошенко 1998: 214-215]. По отношению к ним были применены репрессии. Так, режим лишил многих других аятолл учеников и права получать религиозные налоги, а аятолла Шариатмадари даже лишился права на марджайат (религиозное наставничество). Некоторые высшие богословы были арестованы [Wilfried 2000: 215]. Таким образом, Хомейни, опираясь на свою концепцию абсолютного правления богослова - наместника Сокрытого имама, которому обязаны подчиняться все, в т.Ч. и духовенство, присвоил себе беспрецедентную для традиционного шиизма власть, поставив себя выше всех остальных богословов и применив репрессии к несогласным.

В то же время множество духовных лиц всячески поддерживали придание рахбару очень больших полномочий. Среди современных деятелей можно выделить члена Совета экспертов аятоллу Мохаммада-Таги Месбаха Язди, который считает, что поскольку рахбар (вали-йе факих) избирается Советом экспертов с Божьей помощью, то он является представителем непогрешимого имама, а значит, и сам почти не ошибается в своих действиях. Поэтому люди должны ему подчиняться, не ставя под сомнение его решения. Месбах Язди также заявил, что для определения воли и желаний Сокрытого имама необходимо спрашивать мнение рахбара, тем самым предполагая, что все действия и мысли лидера страны одобряются Сокрытым имамом [Mavani 2011: 812].

Можно также посмотреть, когда впервые по отношению к Хомейни был употреблен термин «имам». Считается, что первый раз его употребил в своих сочинениях выдающийся богослов и мыслитель Мохаммад-Реза Хакими в 1963 г., назвав Хомейни предводителем современных мыслящих шиитов. При этом он в одном и том же предложении, говоря о лидерстве Хомейни, употребил два слова: пишва (вождь, предводитель) и имам. А надо отметить, что само слово «имам» в изначальном смысле переводится с арабского именно как «предводитель»; и в персидском языке слова «пишва» и «имам» являются синонимами, если под термином «имам» не подразумеваются двенадцать непогрешимых имамов. Это означает, что Хакими, употребив этот термин, по всей видимости, не подчеркивал духовную связь Хомейни с пречистыми имамами, а просто обозначил его в качестве выдающегося духовного авторитета и предводителя современных шиитов. Однако такое обозначение Хомейни получило всенародное распространение только после речи нынешнего президента Ирана Хасана Рухани в мечети Арак в Тегеране, произнесенной в конце 1977 г., через 40 дней после убийства сына Хомейни Мустафы, в которой он также назвал Хомейни имамом, вероятно, так же, как и Хакими, подразумевая прежде всего его духовное лидерство ${ }^{1}$. В материале на сайте Национального центра по ответам на религиозные вопросы, который, очевидно, отражает официальную точку зрения правящего духовенства, разъясняется, что термин «имам» по отношению к аятолле Хомейни стоит понимать именно в его изначальном

1 Кто впервые употребил титул «имам» для руководителя Исламской революции? Хасан Рухани или...? - Khabar Online. 27 января 2013 г. Доступ: https://www.khabaronline.

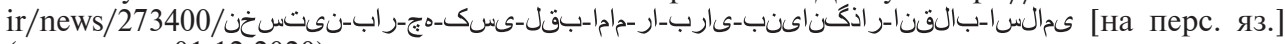
(проверено 01.12.2020). 
этимологическом значении «предводитель». В этом плане он близок к официальному термину «рахбар», использующемуся для обозначения обоих лидеров страны. Термин «имам» применяется к Хомейни потому, что он сумел объединить и возглавить иранских шиитов и осуществить Исламскую революцию, объединив религию и политику, что является редкостью в современном мире. При этом Хомейни нельзя воспринимать как тринадцатого имама - равного по благодати двенадцати непогрешимым имамам, как делают некоторые, поскольку духовный уровень пречистых имамов все-таки выше, чем у него ${ }^{1}$. Тем самым авторы материала поддерживают точку зрения Хакими и других духовных лиц, которые первыми начали называть Хомейни имамом.

Таким образом, можно сказать, что термин «имам», употребляемый по отношению к аятолле Хомейни, воспринимался теми, кто его впервые ввел, в значении выдающегося предводителя шиитской общины, способного устранить угнетателей и установить религиозное правление, и совсем не означал тождества Хомейни с непорочными имамами, поскольку аятолла, при всех достоинствах, все же был обычным человеком и не обладал непогрешимостью, которой иранская традиция наделяет шиитских имамов. Если между ними и можно усмотреть связь, то она заключается в том, что имамы, как и аятолла Хомейни, были авторитетными лидерами верующих и боролись за утверждение и развитие исламской религии.

\footnotetext{
Исследование выполнено в рамках научно-исследовательского проекта РГГУ «Посредничество между реальным и потусторонним миром в религиозных практиках иранщев-щиитов».
}

\section{Список литературы}

Борзуни М.А. 1999. Источник законности исламского правления согласно позиции имама Хомейни. - Имам Хомейни и исламское правление: политическая философия. Тегеран: Организация по сбору и публикации произведений имама Р. Хомейни. С. 65-91 [на перс. яз.].

Дорошенко Е.А. 1998. Шиитское духовенство в двух революциях: 1905-1911 и 1978-1979 г2. М.: ИВ РАН. 237 с.

Кулюшин Н.Д. 2009. Политическое лидерство в шиитском исламе: дис. ... к.полит.н. М. 140 с.

Пархизкар Г.Р. 2014. Исламская революция и рост культа имама Махди в Иране. Кум: Изд-во Исследовательского и образовательного института им. Хомейни. 272 с. [на перс. яз.].

Юртаев В.И. 1993. Иран: студенты в исламской революции. М.: Наука. 218 с.

Mavani H. 2011. Ayatullah Khomeini's Concept of Governance (wilayat al-faqih) and the Classical Shi'i Doctrine of Imamate. - Middle Eastern Studies. Vol. 47. No. 5. P. 807-824.

Taheri A. 1985. The Spirit of Allah. London: Hutchinson. 353 p.

Wilfried B. 2000. Who Rules Iran? The Structure of Power in the Islamic Republic. Washington: The Washington Institute for Near East Policy. 240 p.

\footnotetext{
1 Почему Хомейни называют имамом, а кто-то даже говорит, что он - тринадцатый имам? - Национальный центр по ответам на религиозные вопросы. 04.06.2007. Доступ: https://www.pasokhgoo.ir/node/3514 [на перс. яз.] (проверено 01.12.2020).
} 
FILIN Nikita Aleksandrovich, Dr.Sci. (Hist.), Associate Professor, Head of the Chair for the Modern Eastern Studies, Russian State University for the Humanities (6 Miusskaya Sq, Moscow, Russia, 125993; n.filin@rggu.ru)

\title{
PECULIARITIES OF USE OF THE TERM «IMAM» IN RELATIONSHIP TO THE FOUNDER OF THE ISLAMIC REPUBLIC OF IRAN AYATOLLAH KHOMEINI
}

\begin{abstract}
In modern Iran in relation to the first Supreme Leader of the country Ayatollah Khomeini the term «imam» is constantly applied. In Iranian Shiite tradition, the concept of imam is used not only for the leaders of the prayer of believers, but also for the twelve imams - the descendants of the Prophet Muhammad, who are considered impeccable. According to Shiite beliefs the last imam, Mahdi, went into hiding and will return. In the popular consciousness of Iranians, the image of a strong leader Khomeini was to some extent associated with the image of Imam Mahdi. However, the Iranian clergy denied the possibility of comparing Khomeini with immaculate imams and used the term «imam» in its original meaning - as a leader of the Muslim community, emphasizing his prominent role in leading the Shiites and the Islamic revolution. After coming to power, Khomeini was proclaimed as the governor of Imam Mahdi, which further strengthens his religious and political status and gives him an opportunity to exercise almost unlimited authority.
\end{abstract}

Keywords: Khomeini, Mahdi, imam, leader, legitimacy, clergy 